\title{
A STUDY OF THE RISK FACTORS OF HEPATITIS B AMONG ADULT RURAL POPULATION OF PHULWARI SHARIF BLOCK, PATNA
}

\author{
Alok Kumar', Ajay Kumar², Sweta 3 , Rashmi Singh ${ }^{4}$
}

${ }^{1}$ Tutor, Department of Preventive and Social Medicine, ANMMCH, Gaya.

${ }^{2}$ Senior Resident, Department of Microbiology, Indira Gandhi Institute of Medical Sciences, Patna.

${ }^{3}$ Tutor, Department of Physiology, ANMMCH, Gaya.

4Professor, Department of Preventive and Social Medicine, Patna Medical College and Hospital (PMCH), Patna.

ABSTRACT
BACKGROUND
Hepatitis B is a major public health problem. Approximately, 30\% of world's population or about 2 billion persons have serological
evidence of either current or past infection with this DNA virus. India, with $2-8 \%$ carrier rate contributes to nearly $10 \%$ of the HBV
carrier in the world.
Aims and Objectives- 1. To study the risk factors of Hepatitis B in adult population living in rural areas of Phulwari Sharif Block,
Patna. 2. To study the association and appropriate intervention or public health programme based on study finding.

\section{MATERIALS AND METHODS}

To better define risk factors associated with HBV transmission, we conducted a case-control study consisting of all the adult attendees to the 34 health camps conducted during the study period from June 2012 to May 2013 in each of the 2 randomly selected villages of each subcentre of Phulwari Sharif Block, Patna.

\section{RESULTS}

During the study period of one year, 54 cases were identified as HBsAg positive out of 150, in which 4 cases did not give the consent to participate in the study from among those screened. 100 controls were selected after matching, and enrolled for the study.

\section{CONCLUSION}

The study was an effort to highlight the main risk factors that lead to Hepatitis B virus infection. The present study shows that the known risk factors are also significant in the transmission of Hepatitis B in Bihar.

\section{KEYWORDS}

Hepatitis, Risk Factor.

HOW TO CITE THIS ARTICLE: Kumar A, Kumar A, Sweta, et al. A study of the risk factors of hepatitis B among adult rural population of Phulwari Sharif block, Patna. J. Evolution Med. Dent. Sci. 2017;6(32):2642-2649, DOI: 10.14260/Jemds/2017/570

\section{BACKGROUND}

Hepatitis B virus (HBV) infection is a serious global public health problem with an estimated 2 billion people infected worldwide and 350 million persons with chronic HBV infection. The World Health Organization estimates that 500,000 to 1.2 million deaths occur each year due to HBV related chronic liver disease, and that cirrhosis of the liver and primary hepatocellular carcinoma associated with HBV infection is the 10th leading cause of death worldwide. HBV related hepatocellular carcinoma (HCC) is the $5^{\text {th }}$ most frequent cancer worldwide. ${ }^{1}$

The epidemiology of HBV transmission is complex. Transmission occurs in all age groups associated with percutaneous and permucosal exposure to infectious body fluids from persons with acute or chronic HBV infection.

Financial or Other, Competing Interest: None.

Submission 09-02-2017, Peer Review 08-04-2017,

Acceptance 13-04-2017, Published 20-04-2017.

Corresponding Author:

Dr. Alok Kumar,

Flat No. 401, Mahadeva Niwas,

Ramjaipal Nagar,

Gola Road, Danapur,

Patna-801503.

E-mail:alokmmc@gmail.com

DOI: $10.14260 /$ jemds $/ 2017 / 570$
The highest concentrations of HBV occur in blood and serous fluids, and infection most frequently occurs through direct inoculation of the virus through unsafe injections or reuse of contaminated medical equipment. Other common modes of transmission include sexual contact with infected persons and births from HBV-infected mothers. ${ }^{2}$

As India is in the intermediate endemic region, prevalence of hepatitis B in India among general population ranges from $0.1 \%$ to $11.7 \%$, while it is between $2 \%$ to $8 \%$ in most studies. HBsAg prevalence rate among blood donors ranged from $1 \%$ to $4.7 \%$. With the exception of higher HBsAg positivity in some North-Eastern states ( $\sim 7 \%)$, no substantial geographical variation is apparent in other parts of India. Considering, on an average, HBsAg carrier rate of $5 \%$, the total number of HBV carriers in the country is estimated to be about 50 million, that forms nearly $15 \%$ of the entire pool of HBV carriers in the world and is the second largest pool of chronic HBV infections in the world. ${ }^{3}$ In patients who are suffering from chronic Hepatitis B, cumulative incidence of developing liver cirrhosis over a period of 5 years after diagnosis is $8-20 \%$. Economic burden of treatment of these patients is huge not only for their families but also for health resources of the country. ${ }^{4}$ 
The Quantum of Risk Varies with Different Types of Exposure

a) Needle Stick Injury- If $\mathrm{HBeAg}$ is positive, then there is $37-62 \%$ risk if there is serologic evidence of infection in the recipient. 5

b) Blood Transfusion- The rate of transmission is $52-69 \%$ if transfused with HBsAg positive blood. 6

c) Sexual Exposure- The infection rate seen is $18-40 \%$ in regular partners of HBV infected people; increased risk if history of multiple partners, syphilis, gonorrhoea, receptive anal intercourse. ${ }^{7}$

d) Other Percutaneous Injuries with Blood ExposureThe transmission rates vary between 6-15\% if universal precaution are not followed. ${ }^{8}$

e) Human Bites and Exposure to other Body Fluids (e.g. saliva)- The risk is negligible by human bite in the absence of visible blood. The risk of transmission is very low by saliva. Studies report that if the source is HBeAg positive then they require risk assessment. ${ }^{9}$

Other factors reported to be associated with acquisition of hepatitis B virus infection include age, male gender, low level of education, and history of previous surgery, multiple sexual partner, HIV infection and nonusage of condoms. ${ }^{10}$

\section{Public Health Importance}

- Young children who become infected with the hepatitis B virus are most likely to develop chronic infections, 90\% of infants infected during the first year of life develop chronic infections; $30-50 \%$ of children infected between one to four years of age develop chronic infections.

- In adults, $25 \%$ of adults who become chronically infected during childhood die from hepatitis B related liver cancer or cirrhosis. $90 \%$ of healthy adults who are infected with the hepatitis $B$ virus will recover and be completely rid of the virus within 6 months. ${ }^{11}$

\section{MATERIALS AND METHODS}

An analytic case control study was conducted consisting of all the adult attendees to the 34 health camps conducted during the study period from June 2012 to May 2013 in each of the 2 randomly selected villages of each subcentre of Phulwari Sharif block during the study period of one year, 54 cases were identified as HBsAg positive. Out of these, 4 cases did not give the consent to participate in the study. From among those screened, 100 controls were selected after matching, and enrolled for the study.

Test for Hepatitis B virus surface antigen (HBsAg) was done by ELISA. ELISA microplate Reader is manufactured by BioTek company. $2.5 \mathrm{~mL}$ of blood was taken by intravenous route and collected in labelled vials for each of the participants. The test for HBsAg was done in the $\mathrm{PMCH}$ Laboratory by ELISA Test. All the samples were subjected to test only once and samples testing seropositive for HBsAg by ELISA test were labelled as positive. Two controls were selected for each case and were matched by age, sex, religion, occupation, place of residence, educational status, marital status, and history of Hepatitis B virus vaccination.

\section{Inclusion Criteria}

Adults above 20 years of age visiting the health camps were included.

\section{Exclusion Criteria}

Persons below the age of 20 years, seriously ill and nonconsenting persons.

\section{Selection of Cases and Controls}

Cases and controls were selected from the adult population living in rural area of Phulwari Sharif block, Patna.

\section{Selection of Cases}

Adults above 20 years of age residing in rural area of Phulwari Sharif who tested positive for HBsAg during the course of screening for other conditions by the doctors of Department of Community Medicine at PMCH, Patna.

\section{Selection of Controls}

Controls are taken from the same geographic area, from among those who were serologically negative for HBsAg and matched with respect to age, sex, religion, and geographic location.

\section{Sample Size}

During the study period of one year, 54 cases were identified as HBsAg positive. Out of those, 4 cases did not give the consent to participate in the study and 100 controls were enrolled for the study.

\section{Data Collection}

After selection of cases and controls, subjects were interviewed by a standard questionnaire. The questionnaire mainly covered the following areas: demographic characteristics of the participants, the source of Hepatitis B detection and vaccination status and Hepatitis B transmission determinants. In order to explore more on the mode of transmission, the Hepatitis B transmission determinants part was categorised into three parts-

1. The first was about health care services related determinants, such as receiving blood, invasive surgery (including major or minor), haemodialysis, dental visit, and hospitalisation.

2. The second was about the family source of infection, such as household contact with Hepatitis B carrier or jaundiced patient, family history of Hepatitis B.

3. The third division was about personal and communitybased practices such as intravenous drug use, sharing shaving instruments, sharing toothbrush, shaving at barber shop, piercing, tattoos, history of jail (for more than three months), history of STD, and migrant from different region.

Prior to data collection, the questionnaire was pre-tested with a convenient sample of 10 candidates of the study population to ensure the clarity, time, and ease of administration. Refinements were made on the basis of feedback from the pre-test.

\section{Data Analysis}

Data collected were entered in Microsoft Excel, 2007 and analysis was done by SPSS Version 17.

- Descriptive statistics were computed for the demographic factors of the cases and the controls, and to assess the personal characteristics of the participants. 
- Univariate analysis was performed with odds ratio (OR) calculated for risk factors with Chi-square test. Characteristics that were found, through univariate analysis, to be significantly associated with Hepatitis B infection were entered into a multivariate logistic regression model, to rule out the confounding factors and to determine which characteristics were independent predictors of Hepatitis B infection status of the participant, calculated for the all variables simultaneously.

\section{Ethical Committee Approval}

Approval for the study was obtained from the Institutional Research and Ethics Committee of Patna Medical College vide letter no-1917 of dated 29.05.2013, and conducted after informed consent was obtained from the participants.

- Confidence interval was set at 95\%. P-value of less than 0.05 was considered to indicate st significance.

\section{RESULTS}

The study included 150 participants (50 cases and 100 controls) who agreed to participate in the study and interviewed with a standard questionnaire. The cases and controls were matched for age and sex.

\section{A. Sociodemographic characteristics}

Table 1 shows sociodemographic characteristics of participants. Among 150 cases, $64 \%$ of them were male and about $36 \%$ were female and in controls $65 \%$ were male and $35 \%$ were female. The most common age groups which were positive for HBsAg were between 3035 years were about $32 \%$ in cases followed by $>50$ years about $26 \%$ and in control $26 \%$ and $34 \%$ respectively. $42 \%$ of cases were illiterate and among controls $39 \%$ were illiterate. Regarding the occupation, the majority of cases i.e. about $52 \%$ were labourers and among controls, $49 \%$ were of labour class population. Family size analysis showed $68 \%$ of cases having family size less than 5 and $63 \%$ of controls having family size less than 5 . Regarding per capita income, $34 \%$ of cases having income less than 4000 per month and among controls $43 \%$ of participants having per capita income less than 4000 per month were included as subjects/controls. Nearly $90 \%$ of cases were married and among controls, $82 \%$ were married.

No statistically significant difference was observed between cases and controls with respect to sociodemographic characteristics, as the P-values were $>0.05$.

\begin{tabular}{|c|c|c|c|c|}
\hline Variable & $\begin{array}{c}\text { Case }(n=50) \\
\text { Frequency }(\%)\end{array}$ & $\begin{array}{c}\text { Control }(n=100) \\
\text { Frequency }(\%)\end{array}$ & P-Value@ & $\begin{array}{c}\text { Total }(n=150) \\
\text { Frequency }(\%)\end{array}$ \\
\hline $\begin{array}{c}\text { Age } \\
20-30 \\
31-40 \\
41-50 \\
>50\end{array}$ & $\begin{array}{c}16(32) \\
12(24) \\
9(18) \\
13(26)\end{array}$ & $\begin{array}{l}26(26) \\
21(21) \\
19(19) \\
34(34)\end{array}$ & 0.738 & $\begin{array}{c}42(28) \\
33(22) \\
28(18.7) \\
47(31.3)\end{array}$ \\
\hline $\begin{array}{c}\text { Sex } \\
\text { Male } \\
\text { Female }\end{array}$ & $\begin{array}{l}32(64) \\
18(36)\end{array}$ & $\begin{array}{l}65(65) \\
35(35)\end{array}$ & 0.904 & $\begin{array}{l}97(64.7) \\
53(35.3)\end{array}$ \\
\hline $\begin{array}{c}\text { Education level } \\
\text { Illiterate } \\
\text { Primary } \\
\text { Secondary } \\
\text { Intermediate }\end{array}$ & $\begin{array}{c}21(42) \\
9(18) \\
13(26) \\
7(14)\end{array}$ & $\begin{array}{c}39(39) \\
8(8) \\
30(30) \\
23(23)\end{array}$ & 0.208 & $\begin{array}{c}60(40) \\
17(11.3) \\
43(28.7) \\
30(20)\end{array}$ \\
\hline $\begin{array}{c}\text { Occupation } \\
\text { Housewife } \\
\text { Labourer } \\
\text { Businessman } \\
\text { Office employee } \\
\text { Non-employee }\end{array}$ & $\begin{array}{c}15(30) \\
26(52) \\
2(4) \\
3(6) \\
4(8)\end{array}$ & $\begin{array}{c}31(31) \\
49(49) \\
3(3) \\
3(3) \\
14(14)\end{array}$ & 0.932 & $\begin{array}{c}46(30.7) \\
75(50) \\
5(3.3) \\
6(4) \\
18(12)\end{array}$ \\
\hline $\begin{array}{c}\text { Marital Status } \\
\text { Single } \\
\text { Married } \\
\text { Widow }\end{array}$ & $\begin{array}{c}4(8) \\
45(90) \\
1(2)\end{array}$ & $\begin{array}{c}11(11) \\
82(82) \\
7(7)\end{array}$ & 0.200 & $\begin{array}{c}15(10) \\
127(84.7) \\
8(5.3)\end{array}$ \\
\hline $\begin{array}{c}\text { Family Size } \\
<5 \\
>5\end{array}$ & $\begin{array}{l}34(68) \\
16(32) \\
\end{array}$ & $\begin{array}{l}63(63) \\
37(37)\end{array}$ & 0.447 & $\begin{array}{l}97(64.7) \\
53(35.3)\end{array}$ \\
\hline $\begin{array}{c}\text { Per capita Income } \\
\quad<2000 \\
<4000 \\
<6000 \\
<8000\end{array}$ & $\begin{array}{c}15(30) \\
18(36) \\
12(24) \\
5(10)\end{array}$ & $\begin{array}{c}10(10) \\
55(55) \\
26(26) \\
9(9)\end{array}$ & 0.872 & $\begin{array}{c}25(16.6) \\
73(48.6) \\
38(25.3) \\
14(9.3)\end{array}$ \\
\hline
\end{tabular}


B. Health Care Services Exposure Risk Factors

Table 2 shows univariate analysis regarding health care service related risk factors. To explore the risk factors between cases and controls, many health care services exposure factors were studied, such as; history of blood transfusion, history of surgery (including major or minor), dental visits, and history of hospitalisation.

\begin{tabular}{|c|c|c|c|c|}
\hline Variable & $\begin{array}{c}\text { Case (n_50) } \\
\text { (Frequency) (\%) }\end{array}$ & $\begin{array}{c}\text { Control (n_100) } \\
\text { (Frequency) (\%) }\end{array}$ & p- value & OR (95\% C.I) \\
\hline $\begin{array}{c}\text { History of Blood Transfusion } \\
\text { Yes }\end{array}$ & $10(20)$ & $4(4)$ & & 0.17 \\
No & $40(80)$ & $96(96)$ & $0.004^{*}$ & $0.05-0.56)$ \\
\hline $\begin{array}{c}\text { History of surgery (Major or minor) } \\
\text { Yes }\end{array}$ & $20(40)$ & $22(22)$ & & 0.42 \\
No & $30(60)$ & $78(78)$ & 0.02 & $0.20-0.89)$ \\
\hline Yes & $17(34)$ & $31(31)$ & & 0.87 \\
No & $33(66)$ & $69(69)$ & & $0.42-1.80)$ \\
\hline Yes & $22(44)$ & $25(25)$ & 0.02 & 0.42 \\
No & $28(56)$ & $75(75)$ & $(0.21-0.87)$ \\
\hline
\end{tabular}

A significant relation was found between blood or blood product transfusion and Hepatitis B infection; 10 (20\%) of the cases received blood (or any of its products) compared to $4(4 \%)$ of the controls. This difference in proportions was found to be statistically significant, (P-value $0.004, \mathrm{OR}=0.17$ ).

Forty-two of the participants had a history of surgery in the past. Among those, 20 were cases and 22 were controls. This difference in proportions was found to be statistically significant, (P-value $0.02, \mathrm{OR}=0.42$ ).

Forty-seven participants had a history of hospitalisation. Among those, 22 were cases and 25 were controls, this difference in proportions was found to be statistically significant, (P-value $0.02, \mathrm{OR}=0.42$ ).

The univariate analysis did not show significant differences between cases and controls with regard to dental visit as the Pvalue was $>0.05$.

\section{Personal behaviour related risk factor exposure}

Table 3 shows personal behaviour related risk factor exposure. To explore the risk factors between cases and controls, several personal behaviour related risk factors were studied which included past treatment for STD, pre-used needle stick injury, ear/nose piercing, shaving at barber shop, contact with Hepatitis B patient, family history of Hepatitis B, history of migration and high risk behaviour.

\begin{tabular}{|c|c|c|c|c|}
\hline Variables & $\begin{array}{c}\text { Case (n_50) } \\
\text { (Frequency) (\%) }\end{array}$ & $\begin{array}{l}\text { Controls (n_100) } \\
\text { (Frequency) (\%) }\end{array}$ & p-value & OR (95\% of C.I) \\
\hline $\begin{array}{c}\text { History of STD } \\
\text { Yes } \\
\text { No }\end{array}$ & $\begin{array}{c}6(12) \\
44(88)\end{array}$ & $\begin{array}{c}0(0) \\
100(100)\end{array}$ & $0.002^{*}$ & $0.04(0.002-0.75)$ \\
\hline $\begin{array}{c}\text { Ear/Nose Piercing } \\
\text { Yes } \\
\text { No } \\
\end{array}$ & $\begin{array}{l}17(34) \\
33(66)\end{array}$ & $\begin{array}{l}34(34) \\
66(66)\end{array}$ & 1.00 & $1.00(0.49-2.05)$ \\
\hline $\begin{array}{c}\text { History of pre-used needle stick injury } \\
\text { Yes } \\
\text { No } \\
\end{array}$ & $\begin{array}{c}5(10) \\
45(90)\end{array}$ & $\begin{array}{c}0(0) \\
100(100)\end{array}$ & $0.01^{*}$ & $19.68(1.04-373.32)$ \\
\hline $\begin{array}{c}\text { History of Migration } \\
\text { Yes } \\
\text { No } \\
\end{array}$ & $\begin{array}{l}15(30) \\
35(70)\end{array}$ & $\begin{array}{l}18(18) \\
82(82)\end{array}$ & 0.09 & $0.0 .51(0.23-1.13)$ \\
\hline $\begin{array}{c}\text { High Risk Behaviour } \\
\text { Yes } \\
\text { No } \\
\end{array}$ & $\begin{array}{c}2(4) \\
48(96) \\
\end{array}$ & $\begin{array}{c}0(0) \\
100(100)\end{array}$ & $0.21^{*}$ & $0.16(0.01-4.0)$ \\
\hline $\begin{array}{c}\text { Family history of Hepatitis B } \\
\text { Yes } \\
\text { No } \\
\end{array}$ & $\begin{array}{l}16(32) \\
34(68)\end{array}$ & $\begin{array}{c}8(8) \\
92(92)\end{array}$ & 0.0002 & $5.41(2.12-13.79)$ \\
\hline $\begin{array}{c}\text { Contact with HBV patient } \\
\text { Yes } \\
\text { No }\end{array}$ & $9(18) 41(82)$ & $\begin{array}{c}7(7) \\
93(93)\end{array}$ & 0.04 & $0.34(0.12-0.98)$ \\
\hline
\end{tabular}

\footnotetext{
${ }^{*}$ Fisher's exact test
} 
Six of the participants had a history of treatment of STD in past, all of them were cases. This difference in proportions was found to be statistically significant, (P-value 0.002, $\mathrm{OR}=0.04$ ).

Five of the participants reported being exposed to preused needle stick injury; all of them were among the cases. This difference in proportions was found to be statistically significant, (P-value 0.001, OR=0.05).

Sixteen of the participants had contact with the Hepatitis B patients in the past, and among these 9 were cases and 7 were controls. This difference in proportions was found to be statistically significant, (P-value $0.04, \mathrm{OR}=0.34$ ).

Family history showed $16(32 \%)$ of the Hepatitis B cases had a family member with history of Hepatitis B infection and $8(8 \%)$ of controls had a family member with history of Hepatitis B infection. This difference in proportions was found to be statistically significant, (P-value 0.0002, $\mathrm{OR}=5.41$ ).

Thirty-three of the participants had a history of migration. Among these, 15 were cases and 18 were controls. However, these were not statistically significant (P-value $0.09, \mathrm{OR}=0.51$ ).

The univariate analysis did not show significant differences between cases and controls with regard to ear/nose piercing, history of migration and high risk behaviour history as the P-value was $>0.05$.

\section{Information about Awareness of Hepatitis B}

Nearly $52 \%$ of cases had heard about hepatitis B virus transmission and its risk factors and $65 \%$ of controls had awareness about hepatitis B. About $52 \%$ of cases had history of jaundice in the past and $25 \%$ of controls reported history of jaundice in the past. $46 \%$ of cases and $18 \%$ of controls were tested for hepatitis B in the past, and of these 14 cases had tested positive for hepatitis B in the past.

Past history of jaundice is significantly associated with HBsAg positivity, as the P-value was $<0.05$. As far as vaccination was concerned, only $4 \%$ of cases were vaccinated with hepatitis B vaccine and $13 \%$ controls had been vaccinated with hepatitis $B$ vaccine.

The risk factors was found significant in univariate analysis, and were put to regression model to determine which factors were independent predictors of hepatitis B infection status.

\section{Binary Logistic-Regression Model}

Table 4 shows the binary logistic regression of the risk factors, and shows significant association with the acquisition of Hepatitis B infection. The binary logistic regression model included history of jaundice, history of blood transfusion, past treatment of STD, contact with Hepatitis B patient, history of surgery, history of pre-used needle stick injury, history of hospitalisation and family history of Hepatitis B infection. Controlling for all above mentioned variable, Binary Logistic-Regression Model analysis showed Past history of jaundice and family history of Hepatitis B Virus infection were independently associated with Hepatitis B infection as the P-value was $<0.05$.

\begin{tabular}{|c|c|c|c|c|}
\hline Variable & Case (\%) & Control (\%) & p- value & OR (95\% of C.I) \\
\hline History of Jaundice & $26(52)$ & $25(25)$ & 0.011 & $5.33(2.16-13.16)$ \\
\hline History of Blood Transfusion & $10(20)$ & $4(4)$ & 0.24 & $0.37(0.07-1.99)$ \\
\hline Treatment for STD & $6(12)$ & 0 & 0.75 & $0.04(0.002-0.75)$ \\
\hline Contact with Hepatitis B patient & $9(18)$ & $7(7)$ & 0.87 & $0.89(0.24-3.40)$ \\
\hline History of Surgery & $20(40)$ & $22(22)$ & 0.57 & $0.70(0.20-2.45)$ \\
\hline History of pre-used needle stick injury & $5(10)$ & 0 & 0.81 & $0.05(0.03-0.96)$ \\
\hline History of Hospitalisation & $22(44)$ & $25(25)$ & 0.37 & $0.60(0.20-1.84)$ \\
\hline Family history of Hepatitis B infection & $16(32)$ & $8(8)$ & 0.002 & $0.15(0.45-0.51)$ \\
\hline \multicolumn{4}{|r|}{ Table 4. Binary Logistic Regression Analysis for Hepatitis B Risk Factor } \\
\hline
\end{tabular}

\section{DISCUSSION}

Hepatitis B is a major public health problem that incorporates high economic and social burden. However, it is often neglected because of its largely asymptomatic course with long-term complications. Since the infection has serious consequences, there is still a continuous need to examine its epidemiology so that we can formulate some prevention and control measures. The study was done with the purpose to identify the vulnerable population so that adequate control measures could be incorporated into the health system. The study design chosen was case control, so that significant differences could be identified in those having the risk factors and those who did not.

\section{A. Sociodemographic Characteristics}

Both case and control groups showed male predominance. Among cases, $64 \%$ of them were male and about $36 \%$ were female. In controls, $65 \%$ were male and $35 \%$ were female. It has been shown in the literature that males are at higher risk to develop Hepatitis B infection. No plausible explanation has been given for the higher prevalence in males in the general population but probably females clear the hepatitis B virus more efficiently as compared to males. Another important contributing factor responsible for a higher prevalence among the male population of the study is that plasma disappearance rate for HBsAg in males is lower than females. 12

There are several studies conducted in Egypt, Turkey and Brazil that have shown that male was considered as a risk factor for HBV infection ${ }^{13-15}$ In some studies conducted in Greece, Taiwan and Iran, one of the risk factors mentioned for HBV was male sex.16-18

In another study conducted in Taiwan, risk factors for HBsAg positivity were male sex, age 50 years, and a family history of hepatocellular carcinoma. ${ }^{19}$

The most common age group which were positive for HBsAg was between 20-30 years and there were about 32\% cases, followed by $>50$ years (about 26\%), while and in control $26 \%$ and $34 \%$ cases respectively. The majority of the 
study population was young adults. This result may be due to the rising incidence of risk factors for hepatitis $B$ infection toward the end of adolescence. Also, this is consistent with the allowed age range of blood donation and employment. This age coincides with the onset of high-risk behaviours, such as unsafe sexual practices and injecting drug use. Thus, we hypothesised that these high-risk behaviours are risk factors for infection.

Majority of the participants were illiterate. Among cases, $42 \%$ of them were illiterate and among controls $39 \%$ were illiterate. Study shows that educational level also has an important role in acquiring hepatitis B infection, though our study showed that this was not a significant risk factor.

Regarding the occupation, in a majority of cases about $52 \%$ were labourers and among controls $49 \%$ are from the labour class population. The higher incidences of hepatitis B in these populations were due to risky social activities or unhygienic living habits, and other factors. These factors may increase the risk of contact and rate of infection compared with others. These differences were correlated with a high infection rate, but further investigations are needed for better understanding the mechanisms of these relationships. In our study, $68 \%$ of cases had family size less than 5 and $63 \%$ of controls having family size less than 5 .

Regarding per capita income, $34 \%$ of cases had income less than 4000 per month and among controls, $43 \%$ of participants had per capita income less than 4000 per month. Nearly $90 \%$ of cases were married and among controls, $82 \%$ were married. Results showed both case and controls were well matched, and hence comparable.

Our study did not show any significant difference in sociodemographic characteristics among case and controls, hence sociodemographic characteristics are not statistically significant in our study.

\section{B. Health Care Services Exposure Risk Factors}

The univariate analysis of the data identified history of blood transfusion, history of surgery, history of hospitalisation and past history of jaundice as risk factors for Hepatitis B infection.

\section{Hospitalisation}

Our study showed that history of hospitalisation is significantly associated with hepatitis B infection. About 22 cases had history of hospitalisation in the past. Duration of hospitalisation was also important in these cases, most of them had hospitalisation for more than 7 days.

A study done in India to assess the knowledge and the practice of the nurses and doctors toward the infection and prevention measures, showed the lack of both knowledge and practice, exposing the patients and themselves to nosocomial infection. ${ }^{20}$ This is consistent with what have been shown in study done in different places as in Moldova, in Brazil and in KSA. ${ }^{20}$ In KSA, Bani I conducted a cross sectional study among pregnant women to assess the prevalence of Hepatitis B and its associated factors. They showed that hospitalisation is a significant risk factor for hepatitis B infection. This result could indicate deficiencies in health care workers' knowledge and practice of the standard infection prevention and control precautions in health care settings. ${ }^{21}$

\section{Blood Transfusion}

A significant relation was found between blood or blood product transfusion and Hepatitis B infection; 10 (20\%) of the cases received blood (or any of its products) compared to $4(4 \%)$ of the controls. Thus, blood transfusion is a significant risk factor for Hepatitis B infection, and this might be due to improper screening of blood before transfusion.

A study conducted in Nigeria among pregnant women showed that the history of blood transfusion is a significant risk factor. ${ }^{22}$ Also, a cross sectional study done among health care workers in Uganda showed same results. ${ }^{23}$ This finding supports the conclusion by $\mathrm{Al}-\mathrm{Hindi}$ and colleagues that the routine tests screening of blood units and its products to detect Hepatitis B infection by HBsAg test alone is not enough and there is a need to consider introducing Anti-HBc test and HBV DNA in order to discover the occult HBV, to minimise the risk of HBV transmission by blood and its products. ${ }^{24}$

In Brazil, it was shown that blood transfusion is among the predictors of the HBV exposure. ${ }^{25}$ In two different studies conducted in Italy, blood transfusion and surgical intervention were among the independent risk factors. ${ }^{26.27}$

\section{Surgical Procedure}

Forty-two of the participants had history of surgery in the past, and among them 20 were cases and 22 are controls. This difference in proportions was found to be statistically significant, (P-value 0.02, OR=0.42). Thus, history of surgery either major or minor was significantly associated with the development of hepatitis $\mathrm{B}$ infection. The finding that exposure to unsafe invasive medical procedures contributes to HBV transmission is consistent with other studies, indicating deficiencies in standard infection control precautions in the local health care setting. This may be due to the fact that proper precaution was not taken during surgical procedures. However, performance of some invasive procedures through the informal sector remains a risk, and awareness campaigns directed towards the public need to be launched to raise public demand for safety.

It has been shown in several studies that dental procedures are a risk factor for HBV acquisition due to lack of sufficient knowledge in clinical infection control.28-30 Our study revealed that dental visit is not a risk factor, whereas experimental dental visit increases the chance of HBV infection, possibly due to lack of knowledge and it was found as an independent risk factor for its transmission.

\section{Past History of Jaundice}

Past history of jaundice especially more than 6 months ago is significantly associated with acquiring of hepatitis B infection. Our study reveals that $52 \%$ of cases had past history of jaundice and $25 \%$ of control had past history of jaundice.

\section{Personal Behaviour Related Risk Factors}

The unsafe and unhygienic personal and community practices are risk factors of Hepatitis $B$ transmission. Family history of Hepatitis B, contact with Hepatitis B patient, past treatment of STD and history of pre-used needle stick injury were the most important risk factors. 


\section{Treatment of STD in Past}

Past treatment of STD is significantly associated with acquiring hepatitis B infection, which indicates that STD clinic population may be considered a high risk group, that these risk groups should be screened for HBV and that counselling and contact tracing seems to be of great importance. In our study, $12 \%$ of cases had past treatment of STD.

\section{Family History and Contact with Hepatitis B Person}

The risk of transmission of HBV is known to be high in people who are in contact with chronically infected subjects. ${ }^{31-33}$ In Amazon, the high prevalence among siblings clarifies the importance of personal contact in the transmission of this virus.

In Romania ${ }^{34}$ and Thailand, ${ }^{34}$ the most important risk factor for HBV infection was contact with an infected person. In Greece, one of the major independent risk factor was interfamilial exposure. In Italy, being in the same household as that of a chronic HBsAg carrier was independently associated with hepatitis B. ${ }^{35}$

In France, among military recruits, mention of a family history of hepatitis B was a significant predictor of infection. ${ }^{36}$ In an area of Nepal, household contact was an independent risk factor. ${ }^{37}$ In Korea, it has been shown that HBV has strong familial clustering. 38

Our study also strongly revealed that contact with HBVinfected person is an independent risk factor for its spread. The major spread of HBV infection in the community occurs during childhood and with familial contact. Horizontal transmission related to poor injection practices and sexual behaviour may be important factors for maintaining the spread and prevalence of HBV infection in the community.

\section{Awareness about Hepatitis B}

Many participants did not know about the modes of transmission of hepatitis B, and only about $52 \%$ of cases knew about it, while about $65 \%$ of controls had knowledge about it. Thus, knowledge about mode of transmission is also important in acquiring the disease in the community. Routine screening and vaccination is one of the most important preventative measures adopted to prevent and control Hepatitis B infection at the community level. Our study revealed that only 15 of the study participant reported being vaccinated against Hepatitis B; 2 of the cases and 13 of the controls.

The findings in this study, using the univariate analysis, identified that history of blood transfusion, past history of jaundice, history of surgery and history of hospitalisation, as significant health related risk factors. On the other hand, the significant personal behaviour risk factors are past treatment of STD, contact with a Hepatitis B patient, history of pre-used needle stick injury, and family history of Hepatitis B.

After use of the logistic regression of these risk factors; for control of the confounding factors, just the past history of jaundice and family history of hepatitis B remained the independent risk factor for Hepatitis B transmission.

\section{CONCLUSION}

This case-control study was an effort to highlight the main risk factors that lead to Hepatitis B Virus infection. The present study shows that the known risk factors are also significant in the transmission of Hepatitis B in Bihar.
Migration which is the bane of our state was not significantly associated with hepatitis B infection. The study also suggests that episode of jaundice six month or more in the past, and household contact/family history of hepatitis B are predictors of chronic hepatitis B infection. The role of universal precaution cannot be over emphasised.

It revealed that several high risk behaviours and practices for the transmission of this infection are significantly more prevalent among the cases compared to the controls. Our data indicates that a history of blood transfusion, history of hospitalisation, history of surgery, past treatment of STD and family history of hepatitis B are important risk factors for HBV infection in our area. While the study focused in the rural population of Phulwari Sharif block, Patna, it is likely that similar results may be found elsewhere in the country. Identifying groups at risk for susceptibility can assist in the development of national strategies to target specific groups for cost-effective salvage vaccination programs for adults in the future.

The adoption of infection prevention standards as strategy is the key to Hepatitis B prevention and other blood borne pathogens, while health education for the personal hygiene will protect the public, emphasising on the vaccination of the risky behaviour groups as a first protective line.

However, this study suggests that strategy can be instituted to identify the high risk population with past history of jaundice or contact with a jaundiced person (household contact). This study can help in monitoring the population to detect clearing of HBsAg or followup for further intervention to prevent chronic HBsAg carrier state and its complications.

\section{REFERENCES}

[1] Hepatitis B: Fact Sheets WHO: http://www.who.int/mediacentre/factsheets/fs204/e n.

[2] Chen CJ, Wang LY, Yu MW. Epidemiology of hepatitis B virus infection in Asia pacific region. J Gastrol Hepatol 2000;15(Suppl):E3-6.

[3] Prevention of hepatitis B in India-an overview WHO South-East Asia regional office. New Delhi, 2002.

[4] Perz JF, Armstrong GL, Farrington LA, et al. The contributions of hepatitis $B$ virus and hepatitis $C$ virus infections to cirrhosis and primary liver cancer worldwide. J Hepatol 2006;45(4):529-38.

[5] U.S. Public Health Service. Updated U.S. public health service guidelines for the management of occupational exposures to HBV, HCV, and HIV and recommendations for postexposure prophylaxis. MMWR Recomm Rep 2001;50(RR-11):1-52.

[6] Public health service inter-agency guidelines for screening donors of blood, plasma, organs, tissues, and semen for evidence of hepatitis $B$ and hepatitis C. MMWR Recomm Rep 1991;40(RR-4):1-17.

[7] Inaba N, Ohkawa R, Matsuura A, et al. Sexual transmission of hepatitis B surface antigen. Infection of husbands by HBsAg carrier-state wives. Br J Vener Dis 1979;55(5):366-8.

[8] Gunson RN, Shouval D, Roggendorf M, et al. Hepatitis B virus (HBV) and hepatitis $C$ virus (HCV) infections in health care workers (HCWs): guidelines for prevention of transmission of HBV and HCV from HCW to patients. J Clin Virol 2003;27(3):213-30. 
[9] Hui AY, Hung LC, Tse PC, et al. Transmission of hepatitis $\mathrm{B}$ by human bite--confirmation by detection of virus in saliva and full genome sequencing. J Clin Virol 2005;33(3):254-6.

[10] Bwogi J, Braka F, Makumbi I, et al. Hepatitis B infection is highly endemic in Uganda: finding from a national serosurvey. Afr Health Sci 2009;9(2):98-108.

[11] Chakravarti A, Rawat D, Jain M. A study of perinatal transmission of the hepatitis $\mathrm{B}$ virus. India $\mathrm{J}$ Med Microbial 2005;23(2):128-30.

[12] Nwokediuko S. Risk factors for hepatitis B virus transmission in Nigerians: a case control study. Internet J Gastroenterol 2010;10:1.

[13] Ramlawi and Preventive Medicine Team, 2000: Viral Hepatitis Survey in Palestine.

[14] Nishioka S, Gyorkos TW, Joseph L, et al. Tattooing and risk for transfusion transmitted diseases: the role of the type, number and design of the tattoos, and the conditions in which they were performed. Epidemiol Infect 2002;128(1):63-71.

[15] Salkic NN, Zerem E, Zildzic M, et al. Risk factors for intrafamilial spread of hepatitis B in northeastern Bosnia and Herzegovina. Ann Saudi Med 2009;29(1):41-5.

[16] Torre GL, Miele L, Chiaradi G, et al. Sociodemographic determinants of co-infections by HIV, hepatitis B and hepatitis $\mathrm{C}$ viruses in central Italian prisoners. BMC Infectious Diseases 2007;7:100.

[17] Goh KT, Ding JL, Monteiro EH, et al. Hepatitis B infection in households of acute cases. J Epidemiol Community Health 1985;39(2):123-8.

[18] Smikle M, Dowe G, Hylton-Kong T, et al. Hepatitis B and $C$ viruses and sexually transmitted disease patients in Jamaica. Sex Transm Inf 2001;77(4):295-6.

[19] El-Dalil AA, Jayaweera DT, Walzman M, et al. Hepatitis $B$ markers in heterosexual patients attending two genitourinary medicine clinics in the West Midlands. Genitrurin Med 1997;73(2):127-30.

[20] Russi JC, Serra M, Vinoles J, et al. Sexual transmission of HB, HC. And HIV 1 infections among male transvestite commercial sex workers in Montevideo, Uruguay. Am J Trop Med Hyg 2003;68(6):716-20.

[21] Wilkinson R. Hepatitis B as a sexually transmitted disease in a black South African population. S Afr Med J 1984;65(24):954-5.

[22] Lewis-Ximenez LL, do O KM, Ginuino CF, et al. Risk factors for hepatitis B virus infection in Rio de Janeiro, Brazil. BMC Public Health 2002;2:26.

[23] Pereira LM, Martelli CM, Merchan-Hamann E, et al. Population based multicentric survey of hepatitis B infection and risk factor differences among three regions in Brazil. Am J Trop Med Hyg 2009; 81(2): 240-7.

[24] Sali S, Bashtar R, Alavian SM. Risk factors in chronic hepatitis B infection: a case control study. Hepatitis Monthly 2005;5(4):109-15.
[25] Akhtar S, Younus M, Adil S, et al. Epidemiologic study of chronic hepatitis B virus infection in male volunteer blood donors in Karachi, Pakistan. BMC Gastroenterology 2005;5:26.

[26] Afzal S, Bashir M. Determinants for transmission of hepatitis B and C. Annals King Edward Medical University 2009;15(4):193-6.

[27] Ozer A, Yakupogullari Y, Beytur L, et al. Risk factors of hepatitis B virus infection in Turkey: a population based case control study: risk factors for HBV infection. Hepat Mon 2011;11(4):263-8.

[28] Talaat M, Radwan E, El-Sayed N, et al. Case-control study to evaluate risk factors for acute hepatitis B virus infection in Egypt. EMHJ 2010;16(1):4-9.

[29] Hayajneh WA, Hayajneh YA, Masaadeh HA. A casecontrol study of risk factors for hepatitis B virus infection in North Jordan. J Med Virol 2010;82(2):2203.

[30] Thursz MR. Host genetic factors influencing the outcome of hepatitis. J Viral Hepat 1997;4(4):215-20.

[31] Bani I, Salih M, Maki E, et al. Prevalence and risk factors of hepatitis B virus among pregnant women in Jazan region-Kingdom of Saudi Arabia. Journal of Biology Agriculture and Healthcare 2012;2(7):45-9.

[32] Braka F, Nanyunja M, Makumbi I, et al. Hepatitis B infection among health workers in Uganda: evidence of the need for health worker protection. Vaccine 2006;24(47-48):6930-7.

[33] Jain M, Dogra V, Mishara B, et al. Infection control practices among doctors and nurses in a tertiary care hospital. Ann Trop Med Public Health 2012;5(1):2933.

[34] Omalu I, Jibran A, Olayemi IK, et al. Seroprevalence of malaria and hepatitis B (HBsAg) with associated risk factors among pregnant women attending antenatal clinic in general hospital Minna, North-Central Nigeria. Annual Review \& Research in Biology 2016;2(4):83-8.

[35] Stroffolini T, Mele A, Tosti ME, et al. The impact of the hepatitis B mass immunisation campaign on the incidence and risk factors of acute hepatitis B in Italy. J Hepatol 2000;33(6):980-5.

[36] Stroffolini T, Guadagnino V, Chionne P, et al. A population based survey of hepatitis B virus infection in a southern Italian town. Ital J Gastroenterol Hepatol 1997;29(5):415-8.

[37] Tanaka J. Hepatitis B epidemiology in Latin America. Vaccine 2000;18(Suppl 1):S17-9.

[38] Mendez-Sanchez N, Baptista-Gonzalez H, SanchezGomez RH, et al. The prevalence of hepatitis B and C in

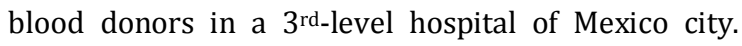
Salud Publica Mex 2016;41:475-8. 